\title{
TWELVE YEARS OF HIGH-RESOLUTION NEAR-SURFACE RADIOMETER DATA PROVIDES INSIGHT INTO END-OF-SEASON CONTROLS IN A DRY GRASSLAND
}

\author{
Lynn M. Moore ${ }^{1,2}$ and William K. Lauenroth ${ }^{1}$
}

\begin{abstract}
The onset of plant dormancy has proven difficult to explain in nearly all ecosystems. Most research has focused on the end-of-season dynamics of deciduous ecosystems, where leaf coloration and leaf fall are the primary phenological responses. More complex are the end-of-season dynamics of grasslands, where the mechanism of dormancy is a gradual response to climatic variables. These complications are magnified in dry grasslands, where the effects of temperature on phenology are modulated by the availability of soil water. Our objectives were to identify the primary drivers influencing the timing of end of season on the shortgrass steppe and determine if the timing of start of season, end of season, or both influences the growing season length of the shortgrass steppe. Our results suggest that temperature and soil water interact to influence the timing of end of season in the shortgrass steppe and that growing season length is strongly related to the date of start of season and less so to the date of end of season. Our findings bear important implications for understanding semiarid ecosystems under climate change. Because future precipitation and temperature tend to diverge, understanding responses in seasonality of greenness as well as productivity in general must take both precipitation and temperature into account.
\end{abstract}

Resumen.-El inicio de la latencia en las plantas ha demostrado ser difícil de explicar en casi todos los ecosistemas. Muchas investigaciones se han enfocado en las dinámicas al final de la temporada de los ecosistemas caducifolios, donde la coloración y la caída de las hojas son respuestas fenológicas primarias. Más complejas son las dinámicas al final de la temporada en los pastizales, donde el mecanismo de latencia es una respuesta gradual a las variables climáticas. Estas complicaciones se magnifican en los pastizales secos, donde los efectos de la temperatura sobre la fenología están modulados por la disponibilidad de agua en el suelo. Nuestros objetivos fueron identificar los principales factores que influyen en el momento final de la temporada en la estepa de pastos cortos y determinar si los tiempos de inicio de la temporada, final de la temporada, o ambos, influyen en la creciente duración de la temporada en la estepa de pastos cortos. Los resultados de nuestro estudio sugieren que la temperatura y el agua en el suelo interactúan para influenciar el tiempo de la temporada en la estepa de pastos cortos y el alargamiento de la temporada está fuertemente relacionada con la fecha de inicio de la temporada y, en menor medida, con la fecha final de la misma. Nuestros hallazgos tienen implicaciones importantes para la comprensión de los ecosistemas semiáridos debido al cambio climático. Como la precipitación y la temperatura futura tienden a diferir, el entender las respuestas en la regularidad estacional así como en la productividad en general, es importante tener en cuenta tanto la precipitación como la temperatura.

Phenology of plants is fundamentally important to ecosystems because it determines seasonal patterns of growth, reproduction, and senescence. These patterns have been researched extensively because climate change can disrupt these patterns thereby influencing annual productivity and the interactions between consumers and producers in ecosystems (Forrest and Miller-Rushing 2010). The onset of spring is advancing with warming (Schwartz et al. 2006, Thompson and Clark 2008, Miller-Rushing and Primack 2008); however, it is less clear how or if climate change affects end-of-season phenology (Estrella and Menzel 2006, Elmore et al. 2012, Dragoni and Rahman 2012). Forested ecosystems senesce as a result of an internally programmed response to changes in temperature, often resulting in brilliant displays of leaf coloring in the fall followed by dormancy until spring. Grassland dormancy is less definable than forest dormancy, as grasses can resume growth whenever environmental conditions are optimal; thus, grasses can green up late in the season after other plants have entered dormancy. Growing season length can be an ecosystem control of annual productivity (Chapin et al. 2002). Changes in growing season length attributed to warming temperatures result from either an advance of the onset of spring, a delay of senescence, or both (Menzel and Fabian 1999, Lemmens et al.

\footnotetext{
${ }^{1}$ University of Wyoming, Department of Botany, 1000 E. University Ave., Laramie, WY 82071.

2E-mail:1moore7@uwyo.edu
} 
2008, Jeong et al. 2011, Zhu et al. 2012). Despite the growing bank of knowledge concerning end-of-season dynamics and growing season length in forested ecosystems (Menzel and Fabian 1999, Jeong et al. 2011, Zhu et al. 2012, Dragoni and Rahman 2012), there are major gaps in our knowledge of how end-ofseason phenology of grasslands may respond to climate change.

Estrella and Menzel (2006) tested several hypotheses regarding possible drivers of end of season in 4 European deciduous tree species. The potential drivers included temperature, soil water balance, warm and/or wet fall weather, and high radiation in the fall. Results varied according to species, but delays in fall leaf coloring due to warm fall temperatures as well as advances in fall leaf coloring occurred due to warm spring temperatures. At coarse spatial resolution, remote sensing studies of deciduous forests in eastern North America have shown that end of season can be explained by elevation and distance from the shoreline (Elmore et al. 2012). However, the variability in end of season is significant and appears to be related to the rate of summer brown down.

More complex are the end-of-season dynamics of grasslands, where the mechanism of dormancy is a gradual response to climatic variables rather than a biologically programmed and climatically triggered leaf coloration and leaf fall (Dalgleish and Hartnett 2006, Klimešová and Klimeš 2007). Indeed, defining an end of season in grasslands similar to the readily definable dormancy of a forested system may be inappropriate, as grasslands tend to linger throughout the fall season in response to available resources. These complications are magnified in arid and semiarid ecosystems, where the effects of temperature on phenology are modulated by the availability of soil water (Dickinson and Dodd 1976, Lesica and Kittelson 2010, Crimmins et al. 2011). Cool season $\mathrm{C}_{3}$ grasses can resume growth under moist conditions if temperatures are above freezing (Dickinson and Dodd 1976).

In dry midcontinental grasslands such as the shortgrass steppe, the majority of precipitation falls during the growing season as rain, with snow having a negligible contribution. Elevated minimum temperatures in the spring can cause decreases in productivity for some species and increases in fall net primary productivity for other species (Alward et al. 1999). Recent work has found that start of season on the shortgrass steppe is initiated by a combination of soil water content at approximately field capacity and soil temperature above $0{ }^{\circ} \mathrm{C}$ (Moore et al. 2015).

The impacts of climate change on a lengthening growing season in wet temperate ecosystems are well documented and predictable, and changes in growing season length can affect carbon cycling, nutrient uptake, and surface energy balance (Menzel and Fabian 1999, Field et al. 2007, Nord and Lynch 2009, Penuelas et al. 2009, Morisette et al. 2009). The lengthening of the growing season can influence net ecosystem productivity (NEP) in both positive and negative ways (White et al. 1999, Dragoni et al. 2011, Parmentier et al. 2011). In dry grasslands, annual productivity is linked to water through the timing and intensity of precipitation (Sala and Lauenroth 1982, Sala et al. 1988, Paruelo and Lauenroth 1995, Heisler-White et al. 2009, Flanagan and Adkinson 2011). Temperate grasslands make up $6 \%$ of the terrestrial area of the earth, accounting for $4.7 \%$ of total terrestrial productivity and encompassing $0.8 \%$ of the biomass on earth (Whittaker and Likens 1973). The largest contiguous grassland on earth is the central grassland region of North America. Temperate grasslands can function either as a carbon source or sink (Dalal and Allen 2008); thus, understanding how these systems are influenced by changing seasonal dynamics would provide a critical contribution to our knowledge of how ecosystems may respond to climate change.

This paper investigates the primary drivers of end of season and growing season length on the shortgrass steppe. To our knowledge this is the first time that end-of-season dynamics have been examined in a semiarid grassland using daily observations of growth, temperature, and water availability. It is important to note that we use observations from a single site located on the shortgrass steppe. Longterm data such as the 12-year radiometric observations presented in this work are infrequent. Even though only a single location is represented, these observations provide a rare opportunity to examine phenological variation in the same ecosystem across years with complementary temperature and precipitation observations. Specifically, we will answer the 


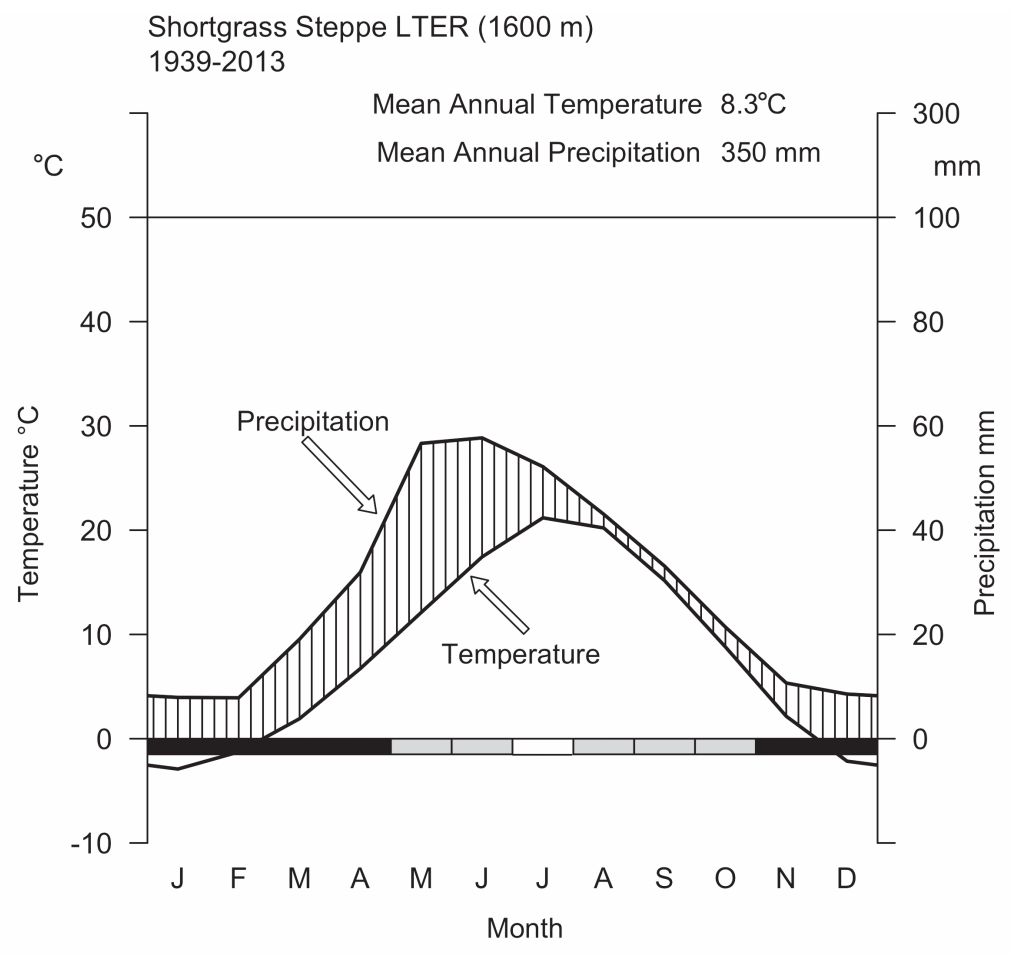

Fig. 1. Climate diagram after Walter and Leith (1967) for the Central Plains Experimental Range (1939-2013). Lined areas indicate periods of relatively humid conditions. Black bars are months with frost; gray bars are months with a chance of frost; white bars are frost-free months.

following questions: (1) How do day length, temperature, and water, interact to control the onset of dormancy on the shortgrass steppe? (2) How do these variables influence the timing of end of season? (3) What factors influence growing season length on the shortgrass steppe?

\section{Methods}

This study was conducted on the Central Plains Experimental Range (CPER) and Shortgrass Steppe Long-Term Ecological Research Site (SGS LTER) located $60 \mathrm{~km}$ east of Fort Collins, Colorado $\left(40^{\circ} 49^{\prime} \mathrm{N}, 104^{\circ} 46^{\prime} \mathrm{W}\right)$. The climate is semiarid continental characterized by a 73-year average annual precipitation of $350 \mathrm{~mm}$ and average annual temperature of $8.3{ }^{\circ} \mathrm{C}$. Temperatures range from $-11^{\circ} \mathrm{C}$ to $29^{\circ} \mathrm{C}$ in winter and summer, respectively (Fig. 1; Walter and Leith 1967, Pielke and Doesken 2008, ARS 2014). The majority of precipitation $(70 \%)$ occurs as rain between April and September. Forty-eight percent of the average annual aboveground biomass consists of the dominant $\mathrm{C}_{4}$ grasses blue grama (Bouteloua gracilis [H.B.K.] Lag.) and buffalo grass (Bouteloua dactyloides [Nutt.] J.T. Columbus). The remaining standing crop is composed of forbs, shrubs, $\mathrm{C}_{3}$ grasses, and cacti (Sims et al. 1978).

We recognize that the use of a single location places limitations on inference. Specifically, our ability to control for factors such as spatial variation in soil characteristics, vegetation cover, or community composition in phenological patterns is constrained (Cleland et al. 2006, 2007, Diez et al. 2012). To show that observations at this location are representative of other sites located on the CPER, we recorded species-specific phenological field observations from years 2001, 2002, 2003, $2004,2005,2006,2007,2009,2010,2011$, and 2012 at a site $2.25 \mathrm{~km}$ southwest of the study site. This procedure allowed us to verify phenological observations on a second location (details in Appendix 1). Given (1) that these auxiliary data indicated that our radiometer 
was representative of general phenological patterns in the shortgrass steppe, (2) that similar long-term data are rare, and (3) that our main focus was on temporal patterns (i.e., interannual variation) and not spatial patterns, our approach of using data from a radiometer at a single location is justified.

\section{Data}

Vegetation indices such as the normalized difference vegetation index (NDVI) have been used at the near-surface scale to record changes in growth (Aase et al. 1987, Goodin and Henebry 1997, Karnieli 2003, Przeszlowska et al. 2006). Observations at the near-surface scale focus on the top of the canopy, which minimizes the degree of shadow intercepted by the sensor. Kume et al. (2011) determined that seasonal changes in the leaf area index (LAI) of a canopy could be estimated by transmitted near infrared and photosynthetically active radiation beneath a canopy measured at near-surface scale. NDVI derived from nearsurface radiometry loses sensitivity with increasing LAI, for example in ecosystems with moderate to dense canopies. However, in sparsely vegetated ecosystems (green leaf LAI between 0 and 2), NDVI is quite sensitive to changing canopy cover (Gamon et al. 1995). In the shortgrass steppe, green leaf LAI peaks at around 0.5 (Knight 1973), which makes this application of near-surface radiometry appropriate to characterize changes in canopy development. In semiarid ecosystems such as the shortgrass steppe, near-surface derived NDVI combined with on-site climate data can be used to gain a detailed understanding of how the timing of plant growth is influenced by temperature and precipitation (Moore et al. 2015).

In 2001, we installed a Skye 1800 2-channel radiometer-channel 1 with a central wavelength in the red $(\mathrm{R})$ at $630 \mathrm{~nm}$ and a spectral range of 590 to $670 \mathrm{~nm}$ and channel 2 with a central wavelength in the near-infrared (NIR) at $862.5 \mathrm{~nm}$ and a spectral range of 750-1100 nm (Skye Instruments, United Kingdom). The sensor was installed in an ungrazed exclosure $2.0 \mathrm{~m}$ above the ground with a viewing window equal to $1.66 \mathrm{~m}^{2}$ ground area. Reflected radiation $\left(\mathrm{MJ} \cdot \mathrm{m}^{-2} \mathrm{~s}^{-1}\right)$ was measured and logged every minute, averaged hourly, and stored on a Campbell Scientific CR10X (Logan, UT) data logger. We calculated the NDVI from the noon-hour average of near-surface reflected radiation measurements:

$$
\mathrm{NDVI}=\frac{\mathrm{NIR}-\mathrm{R}}{\mathrm{R}+\mathrm{NIR}},
$$

(see Appendix 2.1, 2.2; Asrar et al. 1985, Reed et al. 1994, Sellers et al. 1994, Huete et al. 1994, White et al. 2009). We recognize that a single experimental unit imposes limitations on the interpretation of our results. The singleexperimental-unit approach is a common reality in lake ecosystem research and has been well explained in the literature (Schindler 1998, Carpenter et al. 2001, Hansen et al. 2013).

Reflected radiation data were collected in 2001, 2002, 2003, 2004, 2005, 2006, 2007, 2009, 2010, 2011, and 2012. Due to equipment malfunction, data for 2008 were unavailable and only end-of-season data were available for 2001, 2004, 2009, and 2010. Partial data were available for 2010 because the radiometers were taken down for calibration after the plants stopped growing. Plants were brown and senesced at the radiometer site, and senescence was verified with field observations of blue grama and western wheatgrass (Pascopyrum smithii) before removal of the equipment.

We estimated start of season and end of season by the delayed moving average approach based on a 5-d composite period. The start of season was the date when the smoothed NDVI exceeded the dormant winter NDVI 10-d moving average and remained above it for the longest sustained increase in NDVI. The end of season was the date when the smoothed NDVI went below the dormant winter 10-d moving average and remained below it for the longest sustained decrease in NDVI (Reed et al. 1994, White et al. 1997, 2009). To verify the start-of-season and end-ofseason estimates for the measured NDVI we used Spearman's rank correlation to compare the dates to phenological field observations of the dominant warm season grass blue grama and the dominant cool season grass western wheatgrass (see Appendix 1.1, 1.2, 1.3). Specifically the start of season was estimated to be the date when the current year growth equaled the previous year standing dead, and the end of season was estimated as the date when the current year growth showed $\geq 25 \%$ 
browning of the within-plant leaves. Start-ofseason and end-of-season estimates for the years missing NDVI measurements were determined using field observations of blue grama and western wheatgrass.

To understand how changes in insolation influence the onset of dormancy, we used a measure of photoperiod day length (min) defined as the period between sunrise and sunset at the latitude of the shortgrass steppe LTER site (Astronomical Applications Department 2013). Climate data included daily mean, maximum, and minimum air temperature $\left({ }^{\circ} \mathrm{C}\right)$ and daily precipitation $(\mathrm{mm})$. Soil water content was measured at 3 depths $(0-10 \mathrm{~cm}, 10$ $20 \mathrm{~cm}$, and $20-30 \mathrm{~cm}$ ) near the radiometer using Campbell Scientific CS615 (Logan, UT) water content reflectometers. Soil water content was collected hourly, averaged daily, and recorded as daily volumetric soil water content $\left(\mathrm{cm}^{3} / \mathrm{cm}^{3}\right)$. The soil water content was calibrated by comparing the water content reflectometer data to onsite gravimetric soil water measurements at all 3 depths. The resulting corrected volumetric soil water content was analyzed as total daily soil water content from 0 to $30 \mathrm{~cm}$. Soil texture was determined for 8 samples collected within $1 \mathrm{~m}$ of the radiometer window using the hydrometer method. Soil texture $0-30 \mathrm{~cm}$ was sandy loam $(76 \%$ sand, $9 \%$ clay, $15 \%$ silt). To estimate soil water characteristics such as estimated potential evapotranspiration, we used a daily time step soil water simulation model, SOILWAT, which was developed and tested within the shortgrass steppe (Parton 1978, Lauenroth and Bradford 2006, Schlaepfer et al. 2012). SOILWAT is site specific and uses daily weather, monthly vegetation production, and other site-specific properties such as soil texture to simulate the daily shortgrass steppe ecosystem water balance.

To understand how the NDVI responds to temperature, we looked at temperature from 2 directions. First, to understand how the change in the accumulation of heat may influence onset of dormancy, we calculated accumulated growing degree-days (growing degreedays) by the BE method (Baskerville and Emin 1969) using a base temperature of $0{ }^{\circ} \mathrm{C}$ (Goodin and Henebry 1998, Bartholomew and Williams 2005, McMaster 2005) for each calendar year. Second, to determine the influence of a trend in cooling starting from the peak summer temperature to the end of the year, we calculated chilling days by modifying a chill day model (see Appendix 3) to include any temperature at or below a base temperature of $7.5{ }^{\circ} \mathrm{C}$ (Cesaraccio et al. 2004). The base temperature was determined through Pearson's correlation of NDVI and chilling days at 3 base values $\left(5^{\circ} \mathrm{C}, 7.5^{\circ} \mathrm{C}\right.$, and $\left.10{ }^{\circ} \mathrm{C}\right)$; because all 3 temperatures were associated at approximately the same correlation coefficient, we chose to use $7.5^{\circ} \mathrm{C}$ as the base value. Accumulated chilling days (chilling days) prior to end of season were calculated by summing the chilling days. To understand how soil moisture may influence end-of-season dynamics, we included a measure of demand and an estimate of how important daily soil water is prior to the response. We estimated atmospheric demand by calculating the ratio between volumetric soil water content and potential evapotranspiration to represent the demand of water use by vegetation versus atmospheric demand, where higher values indicate higher atmospheric demand. Potential evapotranspiration was estimated using SOILWAT.

\section{Statistical Analysis}

DRIVERS OF END OF SEASON.-To investigate relationships between NDVI and drivers of end-of-season dormancy we used a regression analysis which tested NDVI against day length, growing degree-days, chilling days, soil water content, and atmospheric demand. We analyzed data from 2001 to 2012 , using the time period between 20 July and the end of the year (31 December). July 20th was chosen because data prior to this date were not available for all years. This cutoff date is reasonable because the average date of peak green up for all years is 21 July, day length is decreasing at this point, and July has the highest average mean temperature (Fig. 1). This cutoff restricts the analysis to that portion of the year directly influencing the onset of dormancy. We excluded 2008 due to equipment malfunction. We analyzed individual years and all years combined. See Appendix 4.1 and 4.2 for yearly NDVI observed values plotted over day of year.

We fit all models using a linear mixed effects approach (Zuur 2009) with R package nlme version 3.1-113 (Pinheiro et al. 2013). This approach accounts for variation in NDVI 
responses among years by introducing random effects for the intercept, slope, and interaction parameters. To account for temporal autocorrelation in the residuals, we incorporated an autoregressive error structure. To test whether phenological dynamics differed from year to year, we restricted maximum likelihood (REML) to fit growing degree-days, chilling days, and volumetric soil water content as fixed effects and year as a random effect and then examined the degree of interannual variation in the parameter estimates. Models that did not successfully converge were discarded. The final model was chosen based on AIC (Akaike information criterion) comparisons.

VARIABLES AFFECTING THE TIMING OF END OF SEASON.-We used Pearson's correlation to identify the variables most closely related to the timing of cessation of growth. We calculated several variables during the 30 -d time period leading up to the estimated date of end of season. These variables accounted for how hot the days were (number of days with maximum temperature above $27^{\circ} \mathrm{C}$ ), how cold the nights were (number of days with minimum temperature below $7.5^{\circ} \mathrm{C}$ ), how much precipitation $(\mathrm{mm})$ fell in the $30 \mathrm{~d}$ preceding the estimated end-of-season event, the number of precipitation events above $10 \mathrm{~mm}$ to identify years when the timing of cessation of growth was influenced by large rain events, and the average daily volumetric soil water content $\left(\mathrm{cm}^{3} / \mathrm{cm}^{3}\right)$ during this same period.

GROWING SEASON LENGTH.-Spearman's rank correlation was used to explore the growing season length associations with a variety of possible variables influencing growing season length and the timing of end of season, including start of season, date of first light freeze $\left(-1.7{ }^{\circ} \mathrm{C}\right.$ to $0.0{ }^{\circ} \mathrm{C}$; Koss et al. 1988), first severe freeze (less than $-4.4{ }^{\circ} \mathrm{C}$; Koss et al. 1988), growing degree-days, chilling days, day length, atmospheric demand, and monthly precipitation. We examined growing season length relationships for all 12 years using both NDVI and field observation estimates of end of season and start of season. A Mann-Kendall trend test was used to identify any trend in growing season length across years.

We used the $\mathrm{R}$ base statistical software to run all analyses ( $\mathrm{R}$ Development Core Team 2013, Husson et al. 2013, Pinheiro et al. 2013).

\section{RESUlts}

\section{Drivers of End of Season}

The best explanatory variables for the onset of dormancy were consistent from year to year. Day length was highly correlated with growing degree-days $(r=-0.95, P<0.01)$ and chilling days $(r=0.85, P<0.01)$. Additionally, the mixed effects model did not converge with day length included as a variable, and as a result day length was removed from the model. According to AIC, the following model resulted in a good fit compared to the observed NDVI (Fig. 2):

$$
\begin{aligned}
\text { NDVI }= & \alpha+\beta_{1} \text { Growing degree-days } \\
& +\beta_{2} \text { Soil water content } \\
& +\beta_{3} \text { Growing degree-days } \\
& * \beta_{2} \text { Soil water content, } \quad \text { [Eq. 1] }
\end{aligned}
$$

where growing degree-days, soil water content, and the interaction between growing degree-days and soil water content explained the most variation in NDVI during the onset of dormancy. Excluding the intercept, all regression parameters varied substantially from year to year $(63 \%-81 \%$; Table 1). Partial autocorrelation plots (Appendix 5) indicated that a second-order autoregressive error structure (AR2) was necessary to account for temporal autocorrelation. The estimated autocorrelations for the residuals were 0.55 and 0.32 for the first- and second-order autoregressive terms.

For 10 of the 11 years, growing degree-days showed a significant $(P<0.05)$ negative effect. Growing degree-days tended to cause a decrease in NDVI across all years except 2006, which was a bimodal year with a large pulse in NDVI in September. Soil water content showed a positive effect for all years except 2007 (Table 1). We observed a negative fixed effect of the interaction effect for all 11 years. The growing degree-days by soil water interactions for all years are relatively large and negative, indicating that the NDVI response to soil water is depressed later in the season because of increased growing degree-days (Table 1). This suggests the NDVI response to growing degree-days decreased when soil water was low.

\section{Variables Affecting the Timing of End of Season}

The results of the correlation analysis showed significant associations between the timing of end of season and several important 


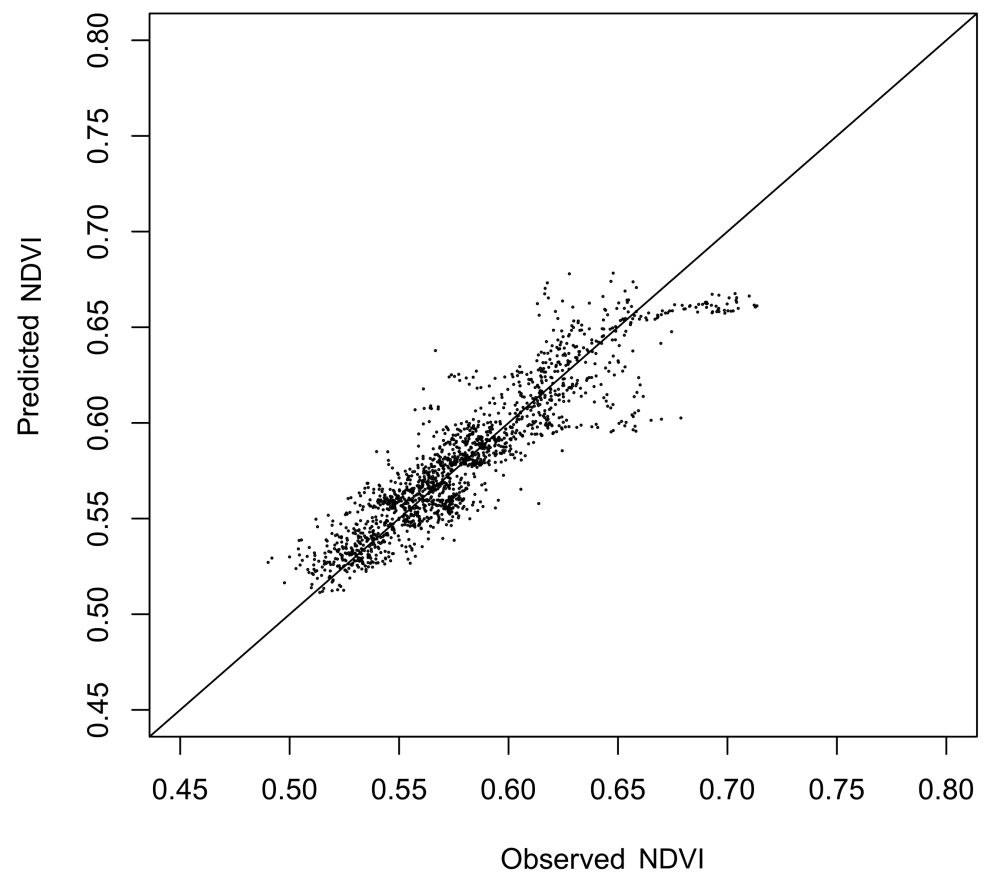

Fig. 2. Predicted NDVI versus observed NDVI for the best-fit model where predicted NDVI = Growing degree-days + chilling days + soil water content + growing degree-days $*$ soil water content [Eq. 1]. Black line has a slope of 1.

TABLE 1. Model fixed effects coefficients within years (2001-2012) and combined model averages across years for growing degree-days $\left(\mathrm{GDD}\right.$, base $\left.=7.5^{\circ} \mathrm{C}\right)$, soil water content $(\mathrm{SWC})$, and their interaction $(\mathrm{GDD} * \mathrm{SWC})$. In parentheses are coefficients of variation $(\% \mathrm{CV})$ for the random effects ([standard deviation for random effect]/[mean fixed effect]) for the average model across years.

\begin{tabular}{lcccc}
\hline Year & Intercept & GDD & Soil water & Interaction \\
\hline 2001 & 0.6114 & -0.0941 & 0.0341 & -0.1879 \\
2002 & 0.6301 & -0.1267 & 0.0462 & -0.3128 \\
2003 & 0.6061 & -0.0927 & 0.0092 & -0.1396 \\
2004 & 0.6924 & -0.1618 & 0.0986 & -0.5082 \\
2005 & 0.6648 & -0.1342 & 0.0438 & -0.3297 \\
2006 & 0.6035 & 0.0139 & 0.0723 & -0.0125 \\
2007 & 0.6246 & -0.0728 & -0.0064 & -0.0604 \\
2009 & 0.6831 & -0.0790 & 0.0638 & -0.4040 \\
2010 & 0.6109 & -0.0622 & 0.0653 & -0.2250 \\
2011 & 0.5870 & -0.0379 & 0.0855 & -0.1967 \\
2012 & 0.1516 & $-0.0903 *(63 \%)$ & 0.1352 & -0.1293 \\
Average & $0.5878 *(25 \%)$ & & $0.0589 *(81 \%)$ & $-0.2278^{*}(75 \%)$ \\
\hline
\end{tabular}

variables within the 30 -d period preceding the estimated date. Positive correlations were found between the date of end of season and the number of large rain events and the number of days below $7.5^{\circ} \mathrm{C}$. Negative correlations were found between the date of end of season and the number of days above $27^{\circ} \mathrm{C}$, average maximum temperature, and average minimum temperature (Table 2).
The correlation analysis showed that large rain events and cooler temperatures can prolong the growing season and that hot temperatures and lack of fall moisture can shorten it. For example, 2011 and 2012 had the latest end-of-season dates (285 and 284, respectively) and each year had a higher number of days below $7.5{ }^{\circ} \mathrm{C}$, lower average minimum temperature, and at least one large precipitation 


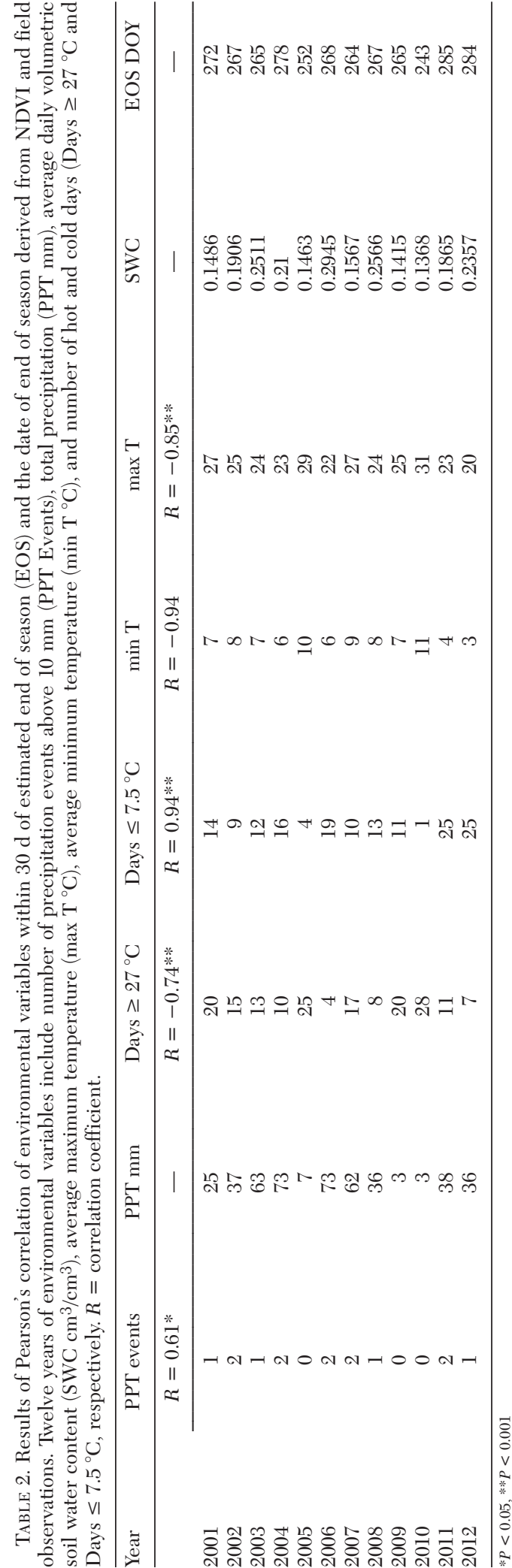

event $(>10 \mathrm{~mm})$ in the $30-\mathrm{d}$ period leading up to the end of season (Table 2). The earliest end-of-season dates occurred in years 2005 and 2010; each had little to no rain in the 30 days prior to end of season, experienced increased average maximum and minimum temperatures, and had an increased number of hot days above $27^{\circ} \mathrm{C}$.

\section{Growing Season Length}

The correlation between date of end of season and start of season was insignificant, suggesting that the processes controlling these events are different (Table 3). Growing season length was strongly negatively associated to the date of start of season and unrelated to date of end of season (Fig. 3). No significant trend was found between growing season length and year, although the positive slope with year hints at a lengthening of the growing season over the 12-year period (Fig. 4, Table 3).

\section{Discussion}

Our objectives were to determine how temperature, water, or a combination of both influence the timing of dormancy on the shortgrass steppe and whether the growing season length of the shortgrass steppe is influenced by the timing of start of season, end of season, or both. Our results suggest that temperature and soil water interact to influence the timing of end of season in the shortgrass steppe and that growing season length is strongly related to the date of start of season and less so to the date of end of season.

\section{Drivers of End of Season}

Boreal and arctic ecosystems are influenced by a strong photoperiod cue, but in temperate systems the influence of photoperiod is variable and not well understood (White et al. 1997, Richardson et al. 2013). For example, in a deciduous broadleaf forest, end of season was sensitive to photoperiod (White et al. 1997, 2002). However, in other temperate locations, photoperiod controls are associated with temperature summations confounding the models (White et al. 1997). In our study, the strong correlation between day length and growing degree-days and chilling days resulted in our removal of photoperiod from the model. The temperature gradients of both growing degree-days and chilling days 
TABLE 3. Factors influencing growing season length from 2001 to 2012. Estimated day of year of start of season and end of season were derived from NDVI and field observations. Growing season length (GSL), annual precipitation (PPT), growing degrees and chilling days from day-of-year 201 to end of season, and atmospheric demand (Atmos demand) at end of season.

\begin{tabular}{lcccccrr}
\hline Year & $\begin{array}{c}\text { Start of } \\
\text { season }\end{array}$ & $\begin{array}{l}\text { End of } \\
\text { season }\end{array}$ & $\begin{array}{l}\text { PPT } \\
(\mathrm{mm})\end{array}$ & $\begin{array}{c}\text { GSL } \\
(\mathrm{d})\end{array}$ & $\begin{array}{c}\text { Growing } \\
\text { degrees }\end{array}$ & $\begin{array}{c}\text { Chilling } \\
\text { days }\end{array}$ & $\begin{array}{c}\text { Atmos } \\
\text { demand }\end{array}$ \\
\hline 2001 & 131 & 272 & 356 & 141 & 1427 & -28.8 & 9.20 \\
2002 & 145 & 267 & 242 & 122 & 1327 & -14.1 & 14.89 \\
2003 & 94 & 265 & 322 & 171 & 1296 & -28.1 & 14.30 \\
2004 & 133 & 278 & 293 & 145 & 1358 & -34.3 & 19.40 \\
2005 & 86 & 252 & 362 & 166 & 1093 & -2.0 & 6.65 \\
2006 & 95 & 268 & 300 & 173 & 1287 & -34.0 & 19.13 \\
2007 & 84 & 264 & 348 & 180 & 1337 & -10.0 & 7.66 \\
2008 & 118 & 267 & 330 & 149 & 1290 & -9.5 & 13.70 \\
2009 & 124 & 265 & 437 & 141 & 1222 & -36.3 & 10.71 \\
2010 & 99 & 243 & 360 & 144 & 944 & -3.7 & 6.66 \\
2011 & 114 & 285 & 356 & 171 & 1556 & -64.9 & 17.42 \\
2012 & 82 & 284 & 175 & 202 & 1505 & -70.5 & 22.87 \\
\hline
\end{tabular}

can function as a proxy for the changes in day length and provide more information surrounding the end-of-season dynamics.

Zhang and Goldberg (2011) modeled endof-season dynamics using MODIS-retrieved NDVI and successfully characterized the change in coloration of fall foliage across a temperate deciduous forest in northeastern North America by developing a brownness index. Due to our calculation of NDVI using reflected radiation, we are limited in calculating a similar index to compare. Additionally, true dormancy does not occur in temperate semiarid grassland, and that system cannot be compared directly to a deciduous forest or a system which is not water limited. In temperate ecosystems, temperature is a primary driver of phenology; however, when water-limited ecosystems such as the shortgrass steppe are considered, the dynamics are less clear. Our study is focused on a $\mathrm{C}_{4}$-dominated grassland with a strong $\mathrm{C}_{3}$ component. $\mathrm{C}_{3}$ plants are well adapted to cooler temperatures and grow vigorously on the shortgrass steppe in the early spring when soil moisture is high and temperatures are relatively low; this strategy also promotes regrowth in the fall. In contrast, $\mathrm{C}_{4}$ plants require more heat to grow, which explains their dominance in the shortgrass steppe during the warm part of the summer season. Because of $\mathrm{C}_{4}$ dominance, the endof-season dynamics are a reflection of $\mathrm{C}_{4}$ grasses responding to the decrease in growing degree-days, even if increases in soil water content are apparent. $\mathrm{C}_{4}$ grasses are going to cease active growth in the presence of low temperature. The increases in NDVI that occur as small bumps from the end-of-season date to the end of the calendar year are likely due to precipitation events that increase soil water availability and temperatures stimulating $\mathrm{C}_{3}$ growth (Dickinson and Dodd 1976, Alward et al. 1999). We took photographs of the radiometer window every $1-2$ weeks during the growing season from 2010 to 2012 . We identified western wheatgrass growing during the late-season pulse in 2011 , verifying that the increase in NDVI was recording $\mathrm{C}_{3}$ growth.

\section{Variables Affecting the Timing of End of Season}

Our results show that end-of-season dynamics on the shortgrass steppe are tied to temperature and soil water (Table 1). Previous work at this site found that start-of-season dynamics are driven by a combination of soil water content approaching field capacity and temperatures warm enough to stimulate growth (Moore et al. 2015). Our results here suggest that different processes are occurring for end of season than for start of season (Table 3). The start of season on the shortgrass steppe occurs as a response to rapid increase in both temperature and moisture (Moore et al. 2015). However, end-of-season growth tends to start and stop in response to changing temperature and moisture conditions. We asked which variables had the most influence in the time period leading up to the date of end of season. We recognize that growth does not suddenly stop on a single day; rather the cessation of growth is a gradual process responding to a change in the limiting factors important for growth on the shortgrass steppe. We reasoned that changes in these 

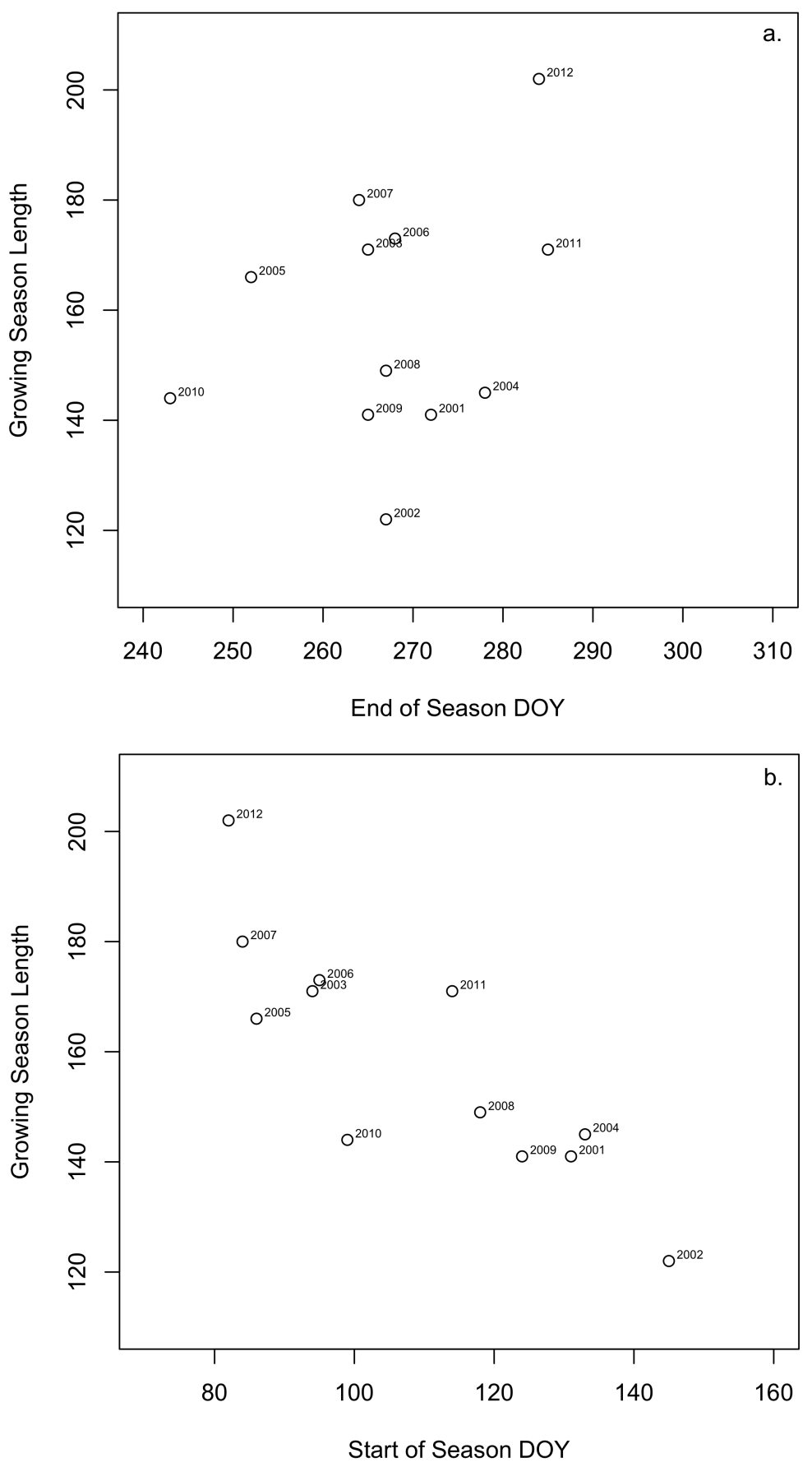

Fig. 3. Spearman's rank correlations between day of year (DOY) of end of season (EOS), start of season (SOS), and growing season length (GSL) with environmental variables from Table 3. Spearman's rank correlations: a, EOS versus $\operatorname{GSL}(\rho=0.18, P=0.5765)$; $\mathbf{b}$, SOS versus GSL $(\rho=-0.86, P<0.05)$.

limiting factors occurring in the preceding $30-\mathrm{d}$ period before cessation of growth would have the most influence upon the timing of dormancy.
Daily temperature averages and moisture observations are complex variables and include maximum and minimum values in the 


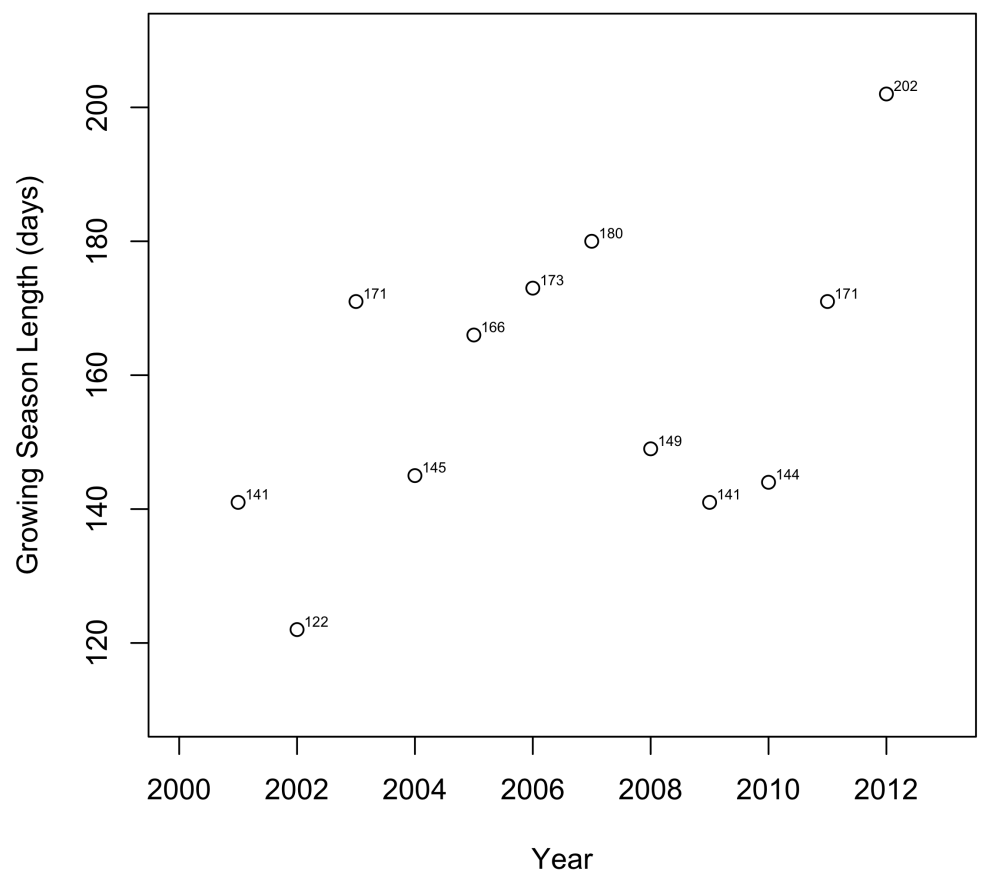

Fig. 4. Growing season length by year for 12 years of NDVI and field observations; numbers are growing season lengths in days. Mann-Kendall trend test statistic $=0.339, P=0.15$.

case of temperature, and precipitation and soil water content in the case of moisture availability. The strongest influence is temperature in the form of hot days and warm nights. Years where the 30-d period preceding end of season was relatively hot and dry tended to exhibit earlier dormancy dates (Tables 2, 3). The second most important influence on endof-season timing was precipitation, which influenced end-of-season dynamics for all years. However, depending on how hot the days were and how cold the nights were, the interaction between temperature and water varied; this effect was accounted for in the mixed effects model (Table 1). For example, the delay of cessation of growth was generally driven by increases in moisture coupled with warm days.

\section{Growing Season Length}

Growing season length is an important influence on aboveground net primary productivity (ANPP) in some ecosystems. The length of the growing season depends on the timing of start of season and end of season. Climate change may influence growing season length in a number of ways, including increases in minimum temperatures and overall mean temperature. Several studies have suggested that increases in growing season length are influenced by delays in end of season (Menzel and Fabian 1999, Elmore et al. 2012, Linares et al. 2012, Zhu et al. 2012). Others have found that start of season or a combination of start of season and end of season may influence growing season length (White et al. 1997, Zhou et al. 2001, Vitasse et al. 2009). Previous work by Alward et al. (1999) suggested that a direct effect of nocturnal temperature increase in the shortgrass steppe may decrease the ANPP of blue grama due to increased respiration. Increases in minimum temperature may also have indirect effects by increasing the growing season length which might favor $\mathrm{C}_{3}$ plants (Alward et al. 1999).

Our results show that growing season length is strongly related to the date of start of season (Fig. 3b). Once growth is initiated in the spring, plants grow in response to available resources, in the case of the shortgrass steppe temperature and moisture. The shortgrass steppe enters the dry season at the same time mean temperatures reach maximum. At the end of season, both temperature and moisture tend to decrease at similar rates (Fig. 1). 
There is a larger window of optimal temperature and moisture in the spring where initiation of growth occurs due to increase in precipitation and increasing temperatures (Fig. 1). As a result, growing season length on the shortgrass steppe is more dependent on the timing of start of season than on the timing of end of season in the shortgrass steppe.

The longest and shortest growing seasons observed during this study occurred under 2 very different precipitation and temperature scenarios. The longest growing season was in 2012. This was an exceptionally dry and warm year. Spring growth was initiated relatively early in March, and very little moisture entered the ecosystem throughout the entire growing season. Large rainfall events $(>10$ $\mathrm{mm}$ ) occurred in September, along with warm daytime temperatures, and the growing season was extended into October, despite the fact that 2012 had high chilling days at the end of season (Table 3).

The shortest growing season observed was in 2010. Annual precipitation was slightly above average (Table 2), with the majority of moisture occurring from 20 April to 20 June. After peak NDVI, $11 \mathrm{~mm}$ of rain fell mostly as events of $\leq 1 \mathrm{~mm}$, with one event producing $4 \mathrm{~mm}$ of moisture. The maximum temperatures between peak and the end of season averaged $31^{\circ} \mathrm{C}$. Chilling days did not accumulate until just before end of season, occurring only on one day; thus, in this particular year, end-of-season dormancy was forced due to low precipitation and warm temperatures.

The growing season length in North America has shown trends toward an overall increase by measures of plant phenology as well as the length of the frost-free season (Myneni et al. 1997, Kunkel et al. 2004, Jeong et al. 2011, Zhu et al. 2012). Growing season length can be a primary control of gross primary production (GPP) (Chapin et al. 2002). Research has suggested that an increased growing season length would increase carbon uptake in some ecosystems such as deciduous forests (White et al. 1999, Nord and Lynch 2009, Dragoni et al. 2011). We compared annual ANPP with growing season length on the shortgrass steppe for 11 years and found no association (Appendix 6), and the results corroborate research that shows precipitation to be the most important control of ANPP on the shortgrass steppe (Sala et al. 1988, Lauenroth and Sala 1992).
We recognize that 12 years of observations is not enough to definitively identify a significant trend in the increase in growing season length at one location on the shortgrass steppe; thus, our study is restricted to observations across time and not space. However, our results do show an increase in the growing season length over the observation time period (Fig. 4). This increase is consistent with other research using remote sensing methods documenting the increase in growing season length in the Great Plains over a considerably longer time period (Reed 2006, Jeong et al. 2011). More importantly, our study suggests that complex interactions are at work, with temperature and soil moisture modulating one another in response to annual variability in climate. Long-term temperature and precipitation averages on the shortgrass steppe show that July is the only frost-free month (Fig. 1). As climate change progresses, frost-free periods and/or extreme weather events, such as severe droughts or intense storm events, may increase with consequences that may influence the growing degree-days and chilling days, as well as precipitation (Hansen et al. 2012). Recent elevated carbon dioxide and warming experiments have shown that increased $\mathrm{CO}_{2}$ resulted in an extended growing season by counteracting the negative effect of warming through conserving water in the soil. This effect was significant in blue grama vegetative growth (Reyes-Fox et al. 2014). Under elevated $\mathrm{CO}_{2}$ and warming, it is likely that the length of the growing season will continue to increase.

\section{ACKNOWLEDGMENTS}

This research was funded through National Science Foundation Grant NSF DEB 0823405. We thank Mark Lindquist, site manager of the SGS LTER; Nicole Kaplan, information manager of the SGS LTER; Kevin Meierbachtol, field crew leader; Trace Martyn, assistant field crew leader; and the SGS LTER field crew for data collection. We also thank Peter Vermeulen for assistance with installing the radiometers and calibrating the soil water sensors and the radiometers. We acknowledge David Bell for assistance with $\mathrm{R}$ code, Daniel Schlepfer for assistance with SOILWAT, and David Smith of USDA ARS for technical assistance with the radiometers. 


\section{Literature Cited}

Aase, J., A. Frank, and R. Lorenz. 1987. Radiometric reflectance measurements of northern Great Plains rangeland and crested wheatgrass pastures. Journal of Range Management 40:299-302.

Alward, R.D., J. Detling, and D. Milchunas. 1999. Grassland vegetation changes and nocturnal global warming. Science 283:229-231.

ARS. 2014. Central Plains Experimental Range climate data. Rangeland Resources Research Unit.

Asrar, G., E. Kanemasu, R. Jackson, and P. Pinter Jr. 1985. Estimation of total above-ground phytomass production using remotely sensed data. Remote Sensing of Environment 17:211-220.

Astronomical Applications Department. 2013. Duration of daylight. U.S. Naval Observatory, Washington, DC.

BartholomeW, P., AND R.D. Williams. 2005. Cool-season grass development response to accumulated temperature under a range of temperature regimes. Crop Science 45:529-534.

Baskerville, G., AND P. Emin. 1969. Rapid estimation of heat accumulation from maximum and minimum temperatures. Ecology 50:514-517.

Carpenter, S.R., J.J. Cole, J.R. Hodgson, J.F. Kitchell, M.L. Pace, D. Blade, K.T. Cottingham, T.E. EssIngton, J.N. Houser, AND D.E. SChindler. 2001. Trophic cascades, nutrients, and lake productivity: whole lake experiments. Ecological Monographs 71 163-186.

Cesaraccio, C., D. Spano, R.L. Snyder, and P. Duce. 2004. Chilling and forcing model to predict budburst of crop and forest species. Agricultural and Forest Meteorology 126:1-13.

Chapin, F.S., III, P.A. Matson, and H.A. Mooney. 2002 Principles of terrestrial ecosystem ecology. Springer, New York, NY.

Cleland, E.E., N.R. Chiariello, S.R. Loarie, H.A MoOneY, AND C.B. Field. 2006. Diverse responses of phenology to global changes in a grassland ecosystem. Proceedings of the National Academy of Sciences 103:13740-13744.

Cleland, E.E., I. Chuine, A. Menzel, H.A. Mooney, AND M.D. SCHWARTZ. 2007. Shifting plant phenology in response to global change. Trends in Ecology and Evolution 22:357-365.

Crimmins, T.M., M.A. Crimmins, and C.D. Bertelsen. 2011. Onset of summer flowering in a "sky island" is driven by monsoon moisture. New Phytologist 191: 468-479.

Dalal, R.C., AND D.E. Allen. 2008. Turner Review No. 18. Greenhouse gas fluxes from natural ecosystems. Australian Journal of Botany 56:369-407.

Dalgleish, H.J., and D.C. Hartnett. 2006. Belowground bud banks increase along a precipitation gradient of the North American Great Plains: a test of the meristem limitation hypothesis. New Phytologist 171:81-89.

Dickinson, C., AND J. DodD. 1976. Phenological pattern in the shortgrass prairie. American Midland Naturalist 96:367-378

Diez, J.M., I. Ibáñez, A.J. Miller-Rushing, S.J. MaZer, T.M. Crimmins, M.A. Crimmins, C.D. Bertelsen, AND D.W. INOUYE. 2012. Forecasting phenology: from species variability to community patterns. Ecology Letters 15:545-553.
Dragoni, D., and A.F. Rahman. 2012. Trends in fall phenology across the deciduous forests of the eastern USA. Agricultural and Forest Meteorology 157: 96-105.

Dragoni, D., H. Schmid, C. Wayson, H. Potter, C. GrimMOND, AND J. RANDOLPH. 2011. Evidence of increased net ecosystem productivity associated with a longer vegetated season in a deciduous forest in south-central Indiana, USA. Global Change Biology 17:886-897.

Elmore, A.J., S.M. Guinn, B.J. Minsley, and A.D. Richardson. 2012. Landscape controls on the timing of spring, autumn, and growing season length in mid-Atlantic forests. Global Change Biology 18: 656-674.

Estrella, N., And A. Menzel. 2006. Responses of leaf colouring in four deciduous tree species to climate and weather in Germany. Climate Research 32: 253-267.

Field, C.B., D.B. Lobell, H.A. Peters, and N.R. Chiariello. 2007. Feedbacks of terrestrial ecosystems to climate change. Agricultural and Forest Meteorology 32:1-29.

Flanagan, L.B., AND A.C. AdKinson. 2011. Interacting controls on productivity in a northern Great Plains grassland and implications for response to ENSO events. Global Change Biology 17:3293-3311.

Forrest, J., AND A.J. Miller-Rushing. 2010. Toward a synthetic understanding of the role of phenology in ecology and evolution. Philosophical Transactions of the Royal Society B: Biological Sciences 365: 3101-3112.

Gamon, J.A., C.B. Field, M.L. Goulden, K.L. Griffin, A.E. Hartley, G. Joel, J. Penuelas, and R. ValenTINI. 1995. Relationships between NDVI, canopy structure, and photosynthesis in three Californian vegetation types. Ecological Applications 5:28-41.

Goodin, D., And G.M. Henebry. 1997. A technique for monitoring ecological disturbance in tallgrass prairie using seasonal NDVI trajectories and a discriminant function mixture model. Remote Sensing of Environment 61:270-278.

Goodin, D., and G.M. Henebry. 1998. Seasonality of finely-resolved spatial structure of NDVI and its component reflectances in tallgrass prairie. International Journal of Remote Sensing 19:3213-3220.

Hansen, G.J.A., C.L. Hein, B.M. Roth, M.J. Vander Zanden, J.W. Gaeta, A.W. LatzKa, and S.R. CarPENTER. 2013. Food web consequences of long-term invasive crayfish control. Canadian Journal of Fisheries and Aquatic Sciences 70:1109-1122.

Hansen, J., M. Sato, and R. Ruedy. 2012. Perception of climate change. Proceedings of the National Academy of Sciences of the United States of America. 109: E2415-E2423.

Heisler-White, J.L., J.M. Blair, E.F. Kelly, K. Harmoney, AND A.K. KNAPP. 2009. Contingent productivity responses to more extreme rainfall regimes across a grassland biome. Global Change Biology 15: 2894-2904.

Huete, A., C. Justice, And H. Liu. 1994. Development of vegetation and soil indices for MODIS-EOS. Remote Sensing of Environment 49:224-234.

Husson, F., J. Josse, S. Le, and J. Mazet. 2013. May 9. FactoMineR: multivariate exploratory data analysis and data mining with R. http://factominer.free.fr/

JEOng, S.-J., C.-H. Ho, H.-J. GIM, AND M.E. Brown. 2011. Phenology shifts at start vs. end of growing 
season in temperate vegetation over the Northern Hemisphere for the period 1982-2008. Global Change Biology 17:2385-2399.

Karnieli, A. 2003. Natural vegetation phenology assessment by ground spectral measurements in two semiarid environments. International Journal of Biometeorology 47:179-187.

KLIMEŠová, J., AND L. KLIMEš. 2007. Bud banks and their role in vegetative regeneration - a literature review and proposal for simple classification and assessment. Perspectives in Plant Ecology Evolution and Systematics 8:115-129.

KNIGHT, D.H. 1973. Leaf area dynamics of a shortgrass prairie in Colorado. Ecology 54:891-896.

Koss, W.J., J.R. Owenby, P.M. Steurer, and D.S. Ezell. 1988. Freeze/frost data. Pages 1-206 in Climatography of the U.S. 1st edition. Asheville, NC.

Kume, A., K.N. Nasahara, S. Nagai, and H. Muraoka. 2011. The ratio of transmitted near-infrared radiation to photosynthetically active radiation (PAR) increases in proportion to the adsorbed PAR in the canopy. Journal of Plant Research 124:99-106.

Kunkel, K.E., D. Easterling, K. Hubbard, and K. REDMOND. 2004. Temporal variations in frost-free season in the United States: 1895-2000. Geophysical Research Letters 31:L03201.

LAUEnRoth, W., AND J. BRADFORD. 2006. Ecohydrology and the partitioning AET between transpiration and evaporation in a semiarid steppe. Ecosystems 9: 756-767.

Lauenroth, W., and O.E. Sala. 1992. Long-term forage production of North American shortgrass steppe. Ecological Applications 2:397-403.

Lemmens, C., H.J. DeBoeck, C. Zavalloni, I. NiJs, and R. Ceulemans. 2008. How is phenology of grassland species influenced by climate warming across a range of species richness? Community Ecology 9:33-42.

Lesica, P., And P.M. KitTelson. 2010. Precipitation and temperature are associated with advanced flowering phenology in a semi-arid grassland. Journal of Arid Environments 74:1013-1017.

Linares, J.C., F. Covelo, J.A. Carreira, and J.Á. MERINO. 2012. Phenological and water-use patterns underlying maximum growing season length at the highest elevations: implications under climate change. Tree Physiology 32:161-170.

McMaster, G.S. 2005. Phytomers, phyllochrons, phenology and temperate cereal development. Journal of Agricultural Science 143:137-150.

Menzel, A., and P. Fabian. 1999. Growing season extended in Europe. Nature 397:659.

Miller-Rushing, A.J., and R.B. Primack. 2008. Global warming and flowering times in Thoreau's Concord: a community perspective. Ecology 89:332-341.

Moore, L.M., W.K. Lauenroth, D.M. Bell, and D.R. SCHLAEPFER. 2015. Soil water and temperature explain canopy phenology and onset of spring in a semiarid steppe. Great Plains Research 25: $121-138$.

Morisette, J.T., A.D. Richardson, A.K. Knapp, J.I. Fisher, E.A. Graham, J. Abatzoglou, B.E. Wilson, D.D. Breshears, G.M. Henebry, J.M. Hanes, and L. LIANG. 2009. Tracking the rhythm of the seasons in the face of global change: phenological research in the 21st century. Frontiers in Ecology and the Environment $7: 253-260$.
Myneni, R.B., C.D. Keeling, C.J. Tucker, G. Asrar, And R.R. NEMANI. 1997. Increased plant growth in the northern high latitudes from 1981 to 1991. Nature 386:698-702.

Nord, E.A., AND J.P. Lynch. 2009. Plant phenology: a critical controller of soil resource acquisition. Journal of Experimental Botany 60:1927-1937.

Parmentier, F.J.W., M.K. van der Molen, J. van Huissteden, S.A. Karsanaev, A.V. Kononov, D.A. SuzDalov, T.C. MaXimov, and A. Dolman. 2011. Longer growing seasons do not increase net carbon uptake in the northeastern Siberian tundra. Journal of Geophysical Research 116:G04013.

Parton, W.J. 1978. Abiotic section of ELM. In: G.S. Innis, editor, Grassland simulation model. Ecological Studies 26. Springer-Verlag, New York, NY.

Paruelo, J., and W. Lauenroth. 1995. Regional patterns of normalized difference vegetation index in North American shrublands and grasslands. Ecology 76: 1888-1898.

Penuelas, J., T. Rutishauser, and I. Filella. 2009. Phenology feedbacks on climate change. Science 324: 887-888.

Pielke, R.A., And N.J. Doesken. 2008. Climate of the shortgrass steppe. Pages 14-29 in W.K. Lauenroth, editor, Ecology of the shortgrass steppe: a long-term perspective. Long-Term Ecological Research Network Series. Oxford University Press, New York, NY.

Pinheiro, J., D. Bates, S. DebRoy, D. Sarkar, and R Core Team. 2013. nlme: linear and nonlinear mixed effects models. http://cran.us.r-project.org/bin/macosx/ contrib/r-release/nlme_3.1-113.tgz

Przeszlowska, A., M. Trúica, and M. Weltz. 2006. Near-ground remote sensing of green area index on the shortgrass prairie. Rangeland Ecology and Management 59:422-430.

R Development Core Team. 2013. R: a language and environment for statistical computing. Vienna, Austria. http://www.R-project.org

ReED, B.C. 2006. Trend analysis of time-series phenology of North America derived from satellite data. GIScience and Remote Sensing 43:24-38.

Reed, B.C., J. Brown, D. VanderZee, T. Loveland, J. Merchant, and D. Ohlen. 1994. Measuring phenological variability from satellite imagery. Journal of Vegetation Science 5:703-714.

Reyes-Fox, M., H. Steltzer, M.J. Trlica, G.S. McMaster, A.A. Andales, D.R. LeCain, and J.A. Morgan. 2014. Elevated $\mathrm{CO}_{2}$ further lengthens growing season under warming conditions. Nature 510:259-262.

Richardson, A.D., T.F. Keenan, M. Migliavacca, Y. Ryu, O. Sonnentag, and M. Toomey. 2013. Climate change, phenology, and phenological control of vegetation feedbacks to the climate system. Agricultural and Forest Meteorology 169:156-173.

SALA, O.E., AND W. LAUENROTH. 1982. Small rainfall events: an ecological role in semiarid regions. Oecologia 53:301-304.

Sala, O.E., W.J. Parton, L. Joyce, and W. Lauenroth. 1988. Primary production of the central grassland region of the United States. Ecology 69:40-45.

SCHINDLER, D.W. 1998. Replication versus realism: the need for ecosystem-scale experiments. Ecosystems $1: 323-334$.

Schlaepfer, D.R., W. Lauenroth, and J. Bradford. 2012. Ecohydrological niche of sagebrush ecosystems. Ecohydrology 5:453-466. 
Schwartz, M.D., R. Ahas, and A. Aasa. 2006. Onset of spring starting earlier across the Northern Hemisphere. Global Change Biology 12:343-351.

Sellers, P.J., C.J. Tucker, G.J. Collatz, S.O. Los, C.O. Justice, D.A. Dazlich, and D.A. Randall. 1994. A global $1^{\circ}$ by $1^{\circ}$ NDVI data set for climate studies. Part 2: the generation of global fields of terrestrial biophysical parameters from the NDVI. International Journal of Remote Sensing 15:3519-3545.

Sims, P., J. Singh, and W. Lauenroth. 1978. The structure and function of ten western North American grasslands: I. Abiotic and vegetational characteristics. Journal of Ecology 66:251-285.

ThOMpson, R., AND R.M. ClaRk. 2008. Is spring starting earlier? Holocene 18:95-104.

Vitasse, Y., A.J. Porté, A. Kremer, R. Michalet, and S. Delzon. 2009. Responses of canopy duration to temperature changes in four temperate tree species: relative contributions of spring and autumn leaf phenology. Oecologia 161:187-198.

Walter, H., AND H. Leith. 1967. Climate diagram world atlas. Fischer Verlag, Jena, Germany.

White, M.A., K.M. DE Beurs, K. Didan, D.W. Inouye, A.D. Richardson, O.P. Jensen, J. O’Keefe, G. Zhang, R.R. Nemani, W.J.D. van Leeuwen, Et al. 2009. Intercomparison, interpretation, and assessment of spring phenology in North America estimated from remote sensing for 1982-2006. Global Change Biology 15:2335-2359.

White, M.A., R.R. Nemani, P.E. Thornton, and S.W. RUNNING. 2002. Satellite evidence of phenological differences between urbanized and rural areas of the eastern United States deciduous broadleaf forest. Ecosystems 5:260-273.

White, M.A., S.W. Running, and P.E. Thornton. 1999. The impact of growing-season length variability on carbon assimilation and evapotranspiration over 88 years in the eastern US deciduous forest. International Journal of Biometeorology 42:139-145.

White, M.A., P.E. Thornton, and S.W. Running. 1997. A continental phenology model for monitoring vegetation responses to interannual climatic variability. Global Biogeochemical Cycles 11:217-234.

Whittaker, R.H., and G.E. Likens. 1973. Primary production: the biosphere and man. Human Ecology $1: 357-369$.

Zhang, X., And M.D. Goldberg. 2011. Monitoring fall foliage coloration dynamics using time-series satellite data. Remote Sensing of Environment 115:382-391.

Zhou, L., C.J. Tucker, R.K. Kaufmann, D. Slayback, N.V. Shabanov, and R.B. Myneni. 2001. Variations in northern vegetation activity inferred from satellite data of vegetation index during 1981 to 1999. Journal of Geophysical Research 106:20069-20083.

Zhu, W., H. Tian, X. Xu, Y. Pan, G. Chen, and W. Lin. 2012. Extension of the growing season due to delayed autumn over mid and high latitudes in North America during 1982-2006. Global Ecology and Biogeography $21: 260-271$.

ZuUR, A.F. 2009. Mixed effects models and extensions in ecology with R. Springer, New York, NY.

Received 9 October 2015 Accepted 8 February 2016

Appendix 1 on page 158 .

Appendix 2 on page 159.

Appendix 3 on page 160 .

Appendix 4 on pages 160-161.

Appendix 5 on page 162 .

Appendix 6 on page 162 . 
Appendix 1.1. Note. The majority of phenological research is focused upon traditional methods of stage-based field observations or remotely sensed derived vegetation indices. We used nearby species-specific phenological field observations to demonstrate a relationship between the near-surface radiometer-derived normalized difference vegetation index (NDVI) and field observations of 2 dominant grasses on the shortgrass steppe. Appendix 1.2 lists the day of year of end of season (EOS) for the measured NDVI as estimated by the delayed moving average method (Reed et al. 1994, White et al. 2009) and the estimated average day of year of end of season for western wheatgrass (Pascopyrum smithii) and blue grama (Bouteloua gracilis). Appendix 1.3 shows the relationships between the measured NDVI and the species-specific observations. The graph shows a significant association between the measured NDVI EOS date and the average EOS day of year of the field observations (see main text for analysis of end of season). This relationship shows that the radiometers are indeed recording the same phenological events that are occurring at one other location on the shortgrass steppe.

APPENDIX 1.2. Day of year of end of season (EOS) for measured NDVI and the day of year when the current year growth showed $25 \%$ or more browning of the within-plant leaves for blue grama (Bouteloua gracilis), western wheatgrass (Pascopyrum smithii), and the average (AVG) of blue grama and western wheatgrass.

\begin{tabular}{lcccc}
\hline Year & $\begin{array}{c}\text { Day of year } \\
\text { of EOS, } \\
\text { NDVI }\end{array}$ & $\begin{array}{c}\text { Day of year } \\
\text { of EOS, } \\
\text { blue grama }\end{array}$ & $\begin{array}{c}\text { Day of year } \\
\text { of EOS, } \\
\text { western wheatgrass }\end{array}$ & $\begin{array}{c}\text { Day of year } \\
\text { of EOS } \\
\text { AVG field }\end{array}$ \\
\hline 2001 & 249 & 262 & 255 & 259 \\
2002 & 259 & 267 & 267 & 267 \\
2003 & 265 & 268 & 253 & 260 \\
2004 & 278 & 266 & 273 & 270 \\
2005 & 252 & 261 & 236 & 249 \\
2006 & 268 & 280 & 264 & 272 \\
2007 & 264 & 262 & 248 & 255 \\
2009 & 265 & 294 & 251 & 272 \\
2010 & 243 & 248 & 234 & 241 \\
2011 & 297 & 291 & 284 & 288 \\
2012 & 284 & 249 & 225 & 237 \\
\hline
\end{tabular}

\section{Comparison of EOS DOY Between NDVI vs. Field Observations}

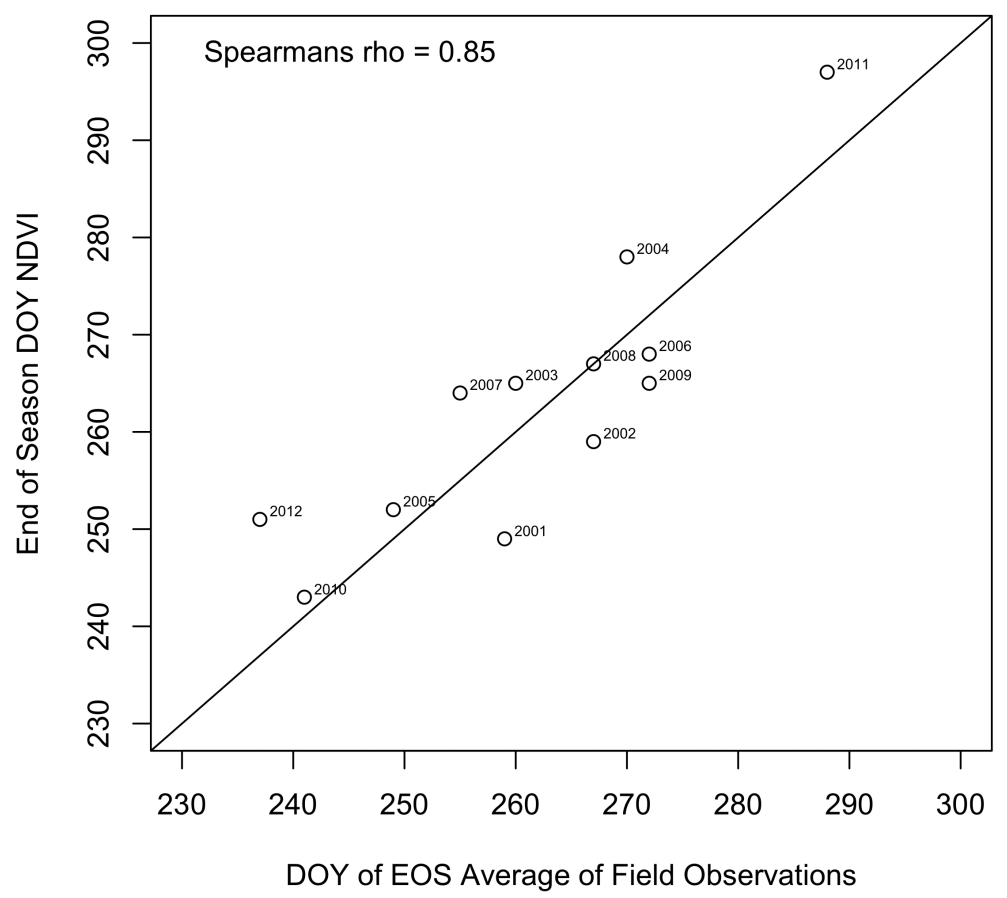

APPENDIX 1.3. Day of year (DOY) of end of season (EOS) for measured NDVI and average of DOY of EOS for average of blue grama (Bouteloua gracilis) and western wheatgrass (Pascopyrum smithii). Black line has a slope of 1 . 
APPENDix 2.1. Note. The normalized difference vegetation index (NDVI) can be calculated from a variety of different spectral sources (Sellers et al. 1994, Huete et al. 1994). In 2001, our study site was installed with one downward-pointing Skye 1800 2-channel radiometer. As a result we only logged the upwelling reflected radiation. Calculating NDVI with only upwelling radiation limited our ability to compare the NDVI between different locations and at different scales. However, despite this limitation, the NDVI calculated as a ratio between the 2 channels of upwelling radiation can still provide valuable information about the seasonal dynamics of the study site. In 2010, an incident light sensor was installed at the end of the year. Using 2 years of these data (2011 and 2012), we compared the NDVI calculated with upwelling radiance only with NDVI calculated using both upwelling radiance and down-welling radiance (i.e., reflectance) and found a strong relationship between the seasonal dynamics and amplitude (Appendix 2.2).
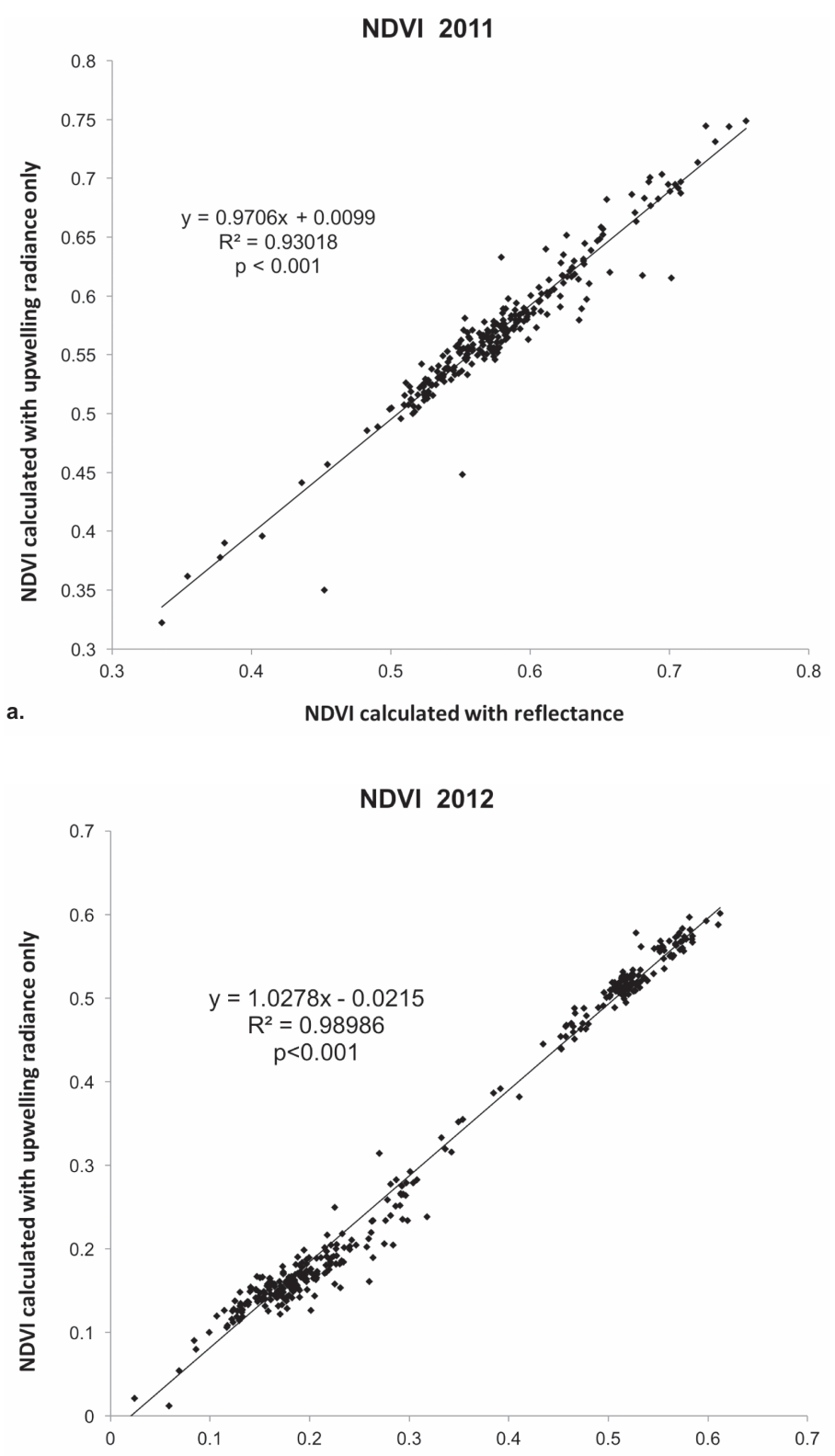

b.

NDVI calculated with reflectance

APPENDIX 2.2. NDVI calculated with upwelling radiance only versus NDVI calculated with both upwelling radiance and down-welling radiance (reflectance): a, 2011; b, 2012. Black line is the linear regression line. 
APPENDIX 3. Calculations used to develop accumulated chilling days modified from Cesaraccio et al. (2004). $\mathrm{T}_{\mathrm{C}}=$ threshold temperature, $\mathrm{T}_{n}=$ minimum temperature, $\mathrm{T}_{\chi}=$ maximum temperature, $\mathrm{T}_{\mathrm{M}}=$ mean temperature.

\begin{tabular}{lc}
\hline Temperature cases & Chill days \\
\hline $0 \leq \mathrm{T}_{\mathrm{C}} \leq \mathrm{T}_{n} \leq \mathrm{T}_{x}$ & $C_{\mathrm{d}}=0$ \\
$0 \leq \mathrm{T}_{n} \leq \mathrm{T}_{\mathrm{C}}<\mathrm{T}_{x}$ & $\mathrm{~T}_{\mathrm{M}}-\mathrm{T}_{\mathrm{n}}\left(\mathrm{T}_{\chi}-\mathrm{T}_{\mathrm{C}}\right) / 2$ \\
$0 \leq \mathrm{T}_{n} \leq \mathrm{T}_{x}$ & $C_{\mathrm{d}}=\mathrm{T}_{\mathrm{M}}-\mathrm{T}_{\mathrm{n}}$ \\
$\mathrm{T}_{n}<\mathrm{T}_{x} \leq \mathrm{T}_{\mathrm{C}}$ & {$\left[\mathrm{T}_{\chi} /\left(\mathrm{T}_{\chi}-\mathrm{T}_{\mathrm{n}}\right)\right]\left(\mathrm{T}_{\chi} / 2\right)$} \\
$\mathrm{T}_{n}<\mathrm{T}_{\mathrm{C}}<\mathrm{T}_{x}$ & {$\left[\mathrm{~T}_{\chi} /\left(\mathrm{T}_{\chi}-\mathrm{T}_{\mathrm{n}}\right)\right]\left(\mathrm{T}_{\chi} / 2\right)-\left[\left(\mathrm{T}_{\chi}-\mathrm{T}_{\mathrm{C}}\right) / 2\right]$} \\
\hline
\end{tabular}
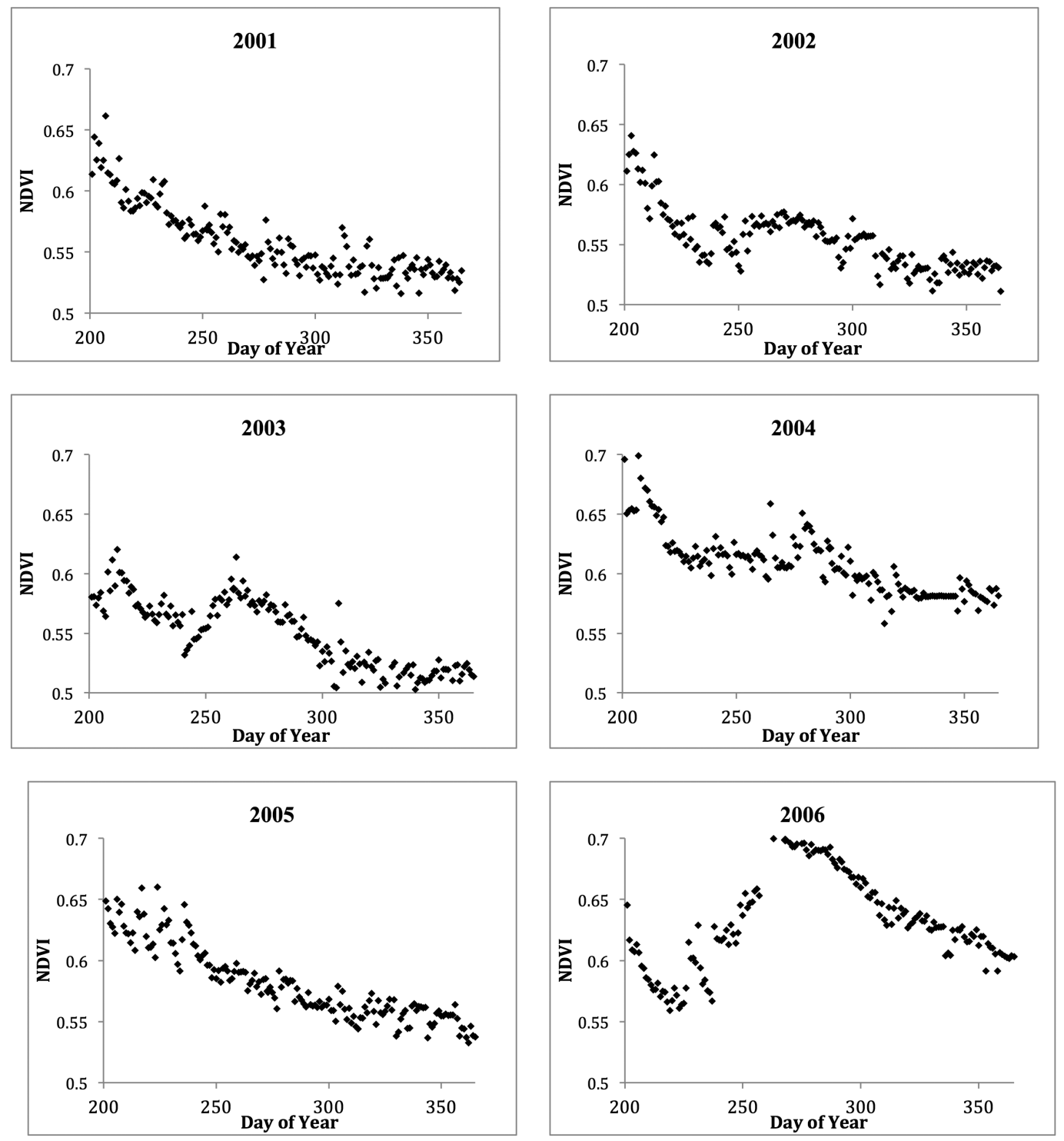

APPENDIX 4.1. NDVI plotted from day-of-year 201 to 365 for the years 2001 to 2006. 

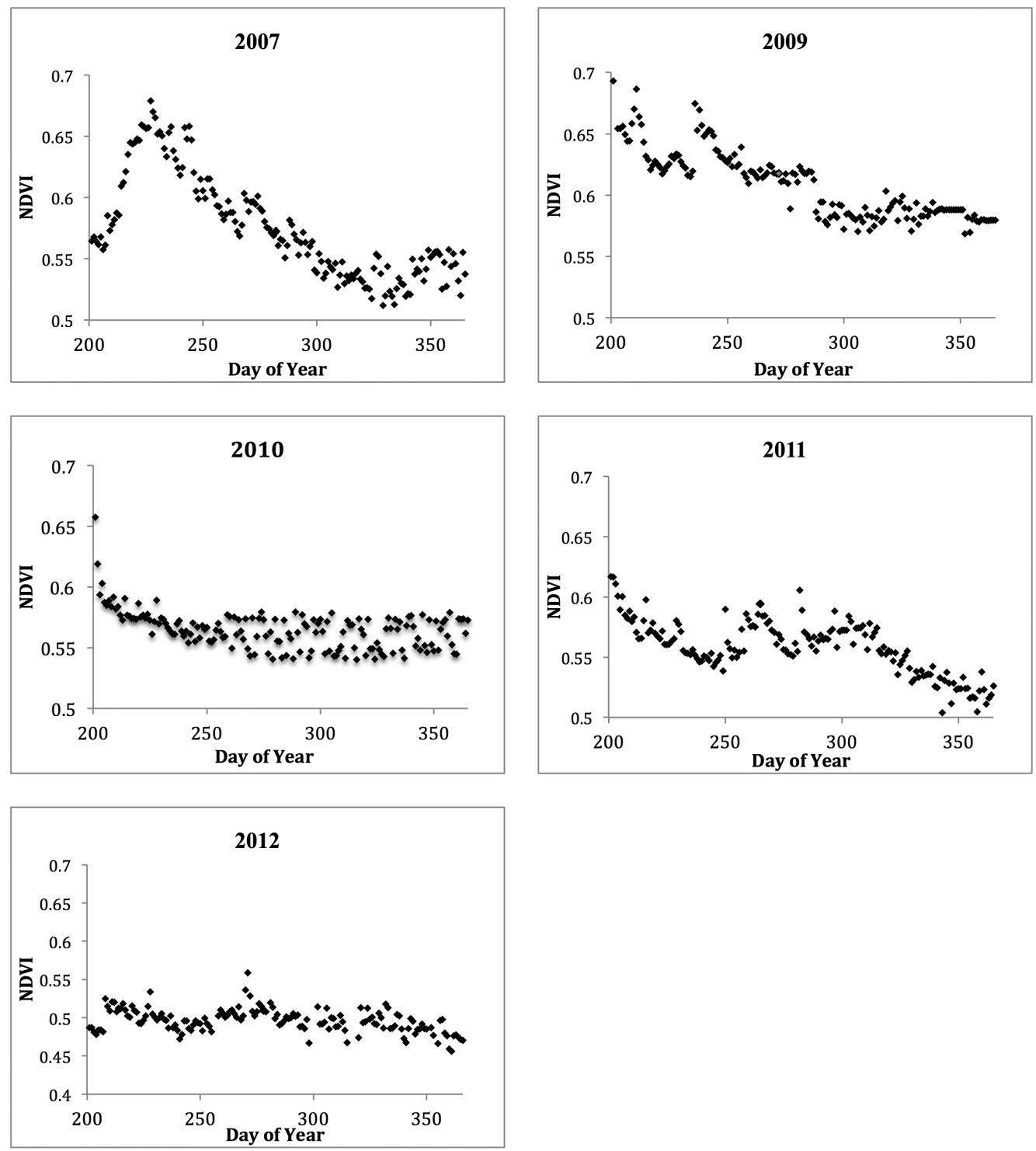

APPENDIX 4.2. NDVI plotted from day-of-year 201 to 365 for the years 2007 to 2012. 
Partial Autocorrelation Plot for Equation [1]

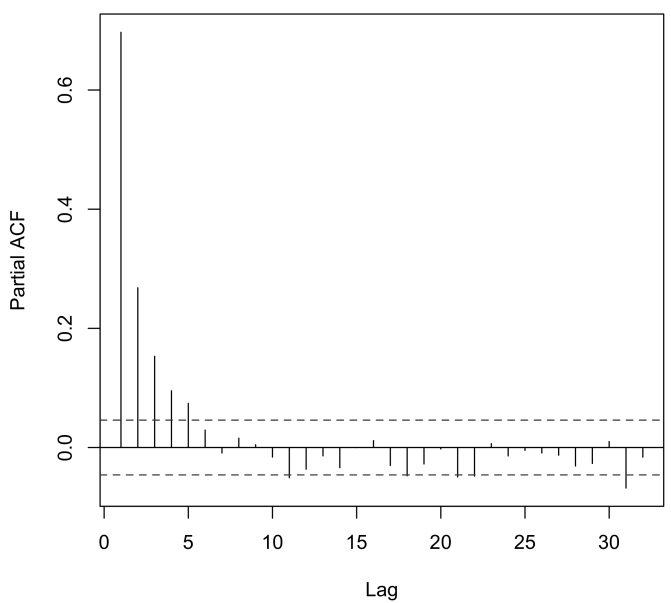

APPENDIX 6. Annual aboveground net primary productivity (ANPP) and growing season length (GSL) from 2001 to 2012 on the shortgrass steppe LTER site. Pearson's correlation between ANPP and GSL: $r=0.008, P=0.98$.

\begin{tabular}{lcc}
\hline Year & $\begin{array}{c}\text { ANPP } \\
\left(\mathrm{g} \cdot \mathrm{m}^{-2}\right)\end{array}$ & $\begin{array}{c}\text { Growing season } \\
\text { length }(\mathrm{d})\end{array}$ \\
\hline 2001 & 70 & 141 \\
2002 & 10 & 122 \\
2003 & 40 & 171 \\
2004 & 26 & 145 \\
2005 & 58 & 166 \\
2006 & 50 & 173 \\
2007 & 71 & 180 \\
2008 & 34 & 149 \\
2009 & 152 & 141 \\
2010 & 140 & 144 \\
2011 & 105 & 171 \\
2012 & 63 & 202 \\
\hline
\end{tabular}

APPENDIX 5. Partial autocorrelation function (ACF) plot for best-fit mixed effects model [Eq. 1]. Autoregressive structure $\mathrm{AR}=2$ 